\title{
Miloslao Pojsl septuagenario
}

\section{Soubor příspěvků vydaný při př́ležitosti životního jubilea}

prof. Miloslava Pojsla

Životní zaměření i vědecký zájem profesora Miloslava Pojsla ovlivnilo jistě jeho rodiště. Chlapecká léta prožívaná ve stínu velehradské baziliky plné krásy, harmonie, uměleckého i historického odkazu podobně jako př́tomnost archeologických vykopávek musely v nadaném studentovi probouzet zvídavost a zájem o hlubší studium.

Velehrad přitahuje jako duchovní magnet celé generace. Tady je možné sahat ke kořenům naší víry i kultury a čerpat $\mathrm{z}$ dávného pramene. Základem dnešní obce je cisterciácký klášter založený r. 1205, či už 1202. Jen čtyři kilometry jsou do Starého Města, kde archeologické vykopávky téměř na kterékoliv zahradě odkrývají stavby z doby Velké Moravy. Nikdo z místních nepochybuje, že právě tam byl Metodějův Velehrad. Cisterciácký Velehrad byl jednou zničen husity a jindy požárem, ale vždy obnoven. Zrušen byl císařem Josefem II., který udělal z baziliky farní kostel a klášter nechal zpustnout. Mocným impulsem pro velkou obnovu byla milénia: 863 příchod věrozvěstů na Moravu, 869 založení biskupství na Moravě a smrt sv. Cyrila, 885 smrt sv. Metoděje.

Duchovní žák Sušilův Antonín Cyril Stojan, pozdější arcibiskup olomoucký, služebník Boží, pochopil sílu velehradského odkazu. Získal a obnovil klášter, který udělal ohniskem mezinárodních snah o sjednocení Slovanů ve víre, kam v roce 1890 byli povoláni jezuité, kteří zde postupně vybudovali své gymnázium a papežskou kolej. Komunistický režim jezuity vyhnal a školy zrušil. Proudům poutníků však zabránit nešlo ani tenkrát. I tehdy se zde čerpala síla $\mathrm{k}$ životu víry a k naději. V roce 1985 právě zde věřící zvedli hlavu proti totalitě. V roce 1990 sem připutoval sám svatý papež Jan Pavel II. a začala se psát nejnovější kapitola Velehradu spojená s mimořádným zájmem veřejnosti a s jeho současnou obnovou.

Není divu, že v takovém prostředí vyroste srdce církevního historika, jehož dotváŕí atmosféra starobylé moravské metropole s biskupským sídlem a univerzitou. $Z$ jeho pera vzešla řada vědeckých i popularizačních prací široké škály církevní archeologie, architektury a umění, sepulkrálních památek, dějin moravských biskupů, ale zvláštní místo v jeho 
badatelských zájmech má přirozeně doba Velkomoravská a cyrilometodějská tradice v dějinách. Mnoho návštěvníků našich kostelů oslovil průvodcovskými publikacemi. Děkuji profesoru Pojslovi za celoživotní dílo, které odráží jeho zájem, pracovitost a houževnatost nejen při vědecké práci, ale i v překonávání nejrůznějších překážek. Přeji mu a vyprošuji ještě mnoho sil, a aby světlo cyrilometodějské víry prozařovalo všechny dny jeho života.

Mons. Jan Graubner 